\title{
Determinants Influencing Entrepreneurial Intention among Undergraduates in Universities of Vietnam
}

\author{
Thi Hong Viet BUI ${ }^{1}$, Thi Le Thuy NGUYEN ${ }^{2}$, Manh Dung TRAN ${ }^{3}$, Thi Anh Thu NGUYEN ${ }^{4}$
}

Received: May 19, 2020 Revised: May 24, 2020 Accepted: June 07, 2020

\begin{abstract}
The paper aims to identify the determinants that influence entrepreneurial intention among National Economics University graduates. For the sample size, we conducted a questionnaire survey of 250 full-time third-year undergraduates at the National Economics University, with convenience sampling technique. Of those 250 undergraduates, 150 were Business Administration students and 100 Economy Management students. After eliminating invalid responses due to lack of information or low quality information, 215 responses were used (93.07\% of respondents) for data analysis. The results show that the factor "Perceived desirability" has the strongest impact on the intention to start a business. It is followed by the factor "Perceived feasibility" in which the "ability to search and plan for start-up" has a stronger influence on undergraduates' entrepreneurial intention than the "leadership and ability to overcome adversity". The hypothesis of a positive relationship between undergraduates' propensity to act and their intention to start a business is also supported in this study. Based on the results, we suggest some recommendations for the university and State management agencies to nurture and develop entrepreneurial intention of undergraduates, forming the young generation of potential entrepreneurs to contribute to the development of emerging countries such as Vietnam, the case study.
\end{abstract}

Keywords: Entrepreneurship, Entrepreneurial Intention, Entrepreneurial Event Model, Vietnam.

JEL Classification Code: L26, L32, M21.

\section{Introduction}

In a time of global integration, the more creative and proactive a country is, the more opportunities it will have to participate in the world's great playground. Entrepreneurship can spark creativity and create new vitality for a nation, and many scholars also argue that entrepreneurship plays an important role in the prosperity of a nation, especially

${ }^{1}$ First Author, $\mathrm{PhD}$, National Economics University, Vietnam. Email: vietbh@neu.edu.vn

${ }^{2}$ Senior Lecturer, PhD, National Economics University, Vietnam. Email: thuyntl@neu.edu.vn

${ }^{3}$ Corresponding Author, Associate Professor, National Economics University, Vietnam [Postal Address: 207 Giai Phong, Hai Ba Trung, Hanoi, 100000, Vietnam] Email: manhdung@ktpt.edu.vn

${ }^{4}$ Lecturer, Academy of Politics Region I, Vietnam.

Email: anhthun19@gmail.com

(c) Copyright: The Author(s)

This is an Open Access article distributed under the terms of the Creative Commons Attribution Non-Commercial License (http://Creativecommons.org/licenses/by-nc/4.0/) which permits unrestricted noncommercial use, distribution, and reproduction in any medium, provided the original work is properly cited. in solving unemployment in society (Amari et al., 2014). Therefore, for many nations nowadays, including Vietnam, the issue of how entrepreneurship is spread and facilitated for development is becoming a major concern of the whole society.

For a new business to emerge, it must be seeded in the intention. According to psychological studies, intention has been proven to be the best predictor of a planned behavior, especially when the behavior is rare, difficult to observe, or includes unpredictable time lag. Intention can have much effect on behavior, in particular, it can account for $30 \%$ of the change in behavior, as opposed to $10 \%$ if explained directly by personalities, personal characteristics, or attitude (Ajzen, 1987). Consequently, identifying the determinants that influence the entrepreneurial intention can be regarded as the first step to develop entrepreneurial behaviors or activities.

Undergraduates or young people are considered to represent the power, the creativity of nations with many dreams and ambitions. Thus, it is very important to encourage the entrepreneurial intention of undergraduates. 
This paper focuses on clarifying key individual factors influencing National Economics University undergraduates' entrepreneurial intention and examining the relationship between those determinants and the entrepreneurial intention of the undergraduates as well. Based on study results, we can give appropriate recommendations to encourage and develop the entrepreneurial intention of National Economics University's undergraduates.

\section{Literature Review}

\subsection{Entrepreneurship, Intention and Entrepreneurial Intention}

The term "entrepreneurship" was first mentioned by French economist Cantillon in 1755 (Hisrich et al., 2005). It is derived from a French word Entreprendre which means to start or to execute (Parker, 2009). Since then, many scholars have come up with different definitions of the terminology in different perspectives. Morris et al. (1994) found more than 70 different definitions of "entrepreneurship". Almost definitions are related to starting a new business, or selfemployed. Other definitions emphasize a wide range of activities, including organization creation, resources combination in new ways, exploration of opportunities, and risk-taking acceptance. Schumpeter (1934) argued that "entrepreneurship" is the spirit of creativity and innovation. Also, according to Drucker (1985), "entrepreneurship" is a creative activity that involves taking advantage of available resources to create wealth in a new way. Bygrave and Timmons (1992) also asserted that "entrepreneurship" is a process of creating or seizing opportunities and pursuing it despite current resources. Shane and Venkataraman (2000) argued that "entrepreneurship" reflects discovery, access and exploitation of opportunities, new products, new services or new production processes; new strategies and organizational forms and new markets for products and inputs that have not existed so far. From those perceptions of entrepreneurship mentioned above, we propose entrepreneurship as starting a new business process. This process requires creativity and innovation to create or seize business opportunities, leverage available resources, take risks of engaging in business ventures with the goals of wealth, independence or providing some values to society.

"Intention" is described as a specific tendency of each individual to perform an action or a series of actions. It is the result of a conscious thinking process that can orient behaviors (Parker, 2004). According to Bird (1998), "intention" can be defined as a state of mind that directs one's concentration and activities toward a particular goal or the way to achieve something.

As mentioned above, the term "entrepreneurship" is considered from various angles by researchers. Therefore, unsurprisingly, the term "entrepreneurial intention" is also used in many different ways. However, most studies regard "entrepreneurial intention" as a state of mind that is shaped before entrepreneurial behaviors happen. Krueger (1993) definded "entrepreneurial intention" as a commitment to start a business. This intention indicates the potential or tendency of an individual to start a new business in the future. Until 2005, in another study, he added that entrepreneruial intention can be viewed as a cognitive process that is identified immediately before the act of starting a business. In addition, Thompson (2009) argued that entrepreneurial intention can be considered as a consious identification of mind, aiming to promote neccessary actions to start a business. And this study proposes an approach toward entrepreneurial intention as a state of mind that directs a person's focus, abilites, and activities to start a new business.

\subsection{Entrepreneurial Intention Theoretical Models}

Previous studies have used a variety of methods to discover what determinants could affect an individual's entrepreneurial behaviors. Initially, some researchers suggested that individual characteristics may have an impact on this behavior. However, with the assumption of unchangeable entrepreneurs' traits, attitudes, and beliefs after entrepreneurial experience, this approach had limitation for just focusing on ex-post situations, which means after entrepreneurial event happens. Later on, researchers shifted to study demographic variables, including features such as age, gender, education, or extend examination to other factors such as contextual or enviromental conditions. However, all of these determinants have limited explanatory power in predicting an individual's entrepreneurship decision. Thus, from 1990s, scientists focused on pre-decicion stages, and develop intention-based models for predicting entrepreneurial behaviors.

Intention is a reliable predictor of planned behavior in a variety of situations (Ajzen \& Fishbien, 1980; Ajzen, 1991). Moreover, entrepreneurship is classified as a planned behavior because the thinking process to identify opportunities and emphasize them over risks is obviously a deliberate process (Krueger, 1993; Krueger et al., 2000). Thus, among all the determinants examined as potential predictors for entrepreneurial behavior, the entrepreneurial intention was proved to be the strongest one. (Gartner, 1985; Krueger et al., 2000). In addtion, understanding the factors influencing entrepreneurial intention also increase the knowledge of entrepreneurial behavior. Krueger and Brazeal (1994) asserted that prior to entrepreneurial behavior, there should be a entrepreneurial potential. This indicated that entrepreneurial intention studies play an important role in encouraging entrepreneurship, involving efforts of universities and colleges. 
According to Guerrero et al. (2008), there are five main theoretical models for entrepreneurial intention. They are Entrepreneurial Event model (Shapero \& Sokol, 1982); Planned Behavior Theory model (Ajzen, 1991), applied in the field of entrepreneurship by Kovereid (1997); Entrepreneurial Attitude Orientation model (Robinson et al., 1991); Entrepreneurial Potential model (Krueger \& Brazeal, 1994); and Davisson model (1995). Among them, there are two theoretical models that have been recognized, tested and widely used in the world: Entreprenerial Event model by Shapero and Sokol (1982) and model of Planned Behavior Theory by Ajzen (1991). Both models proved to be useful tools for predicting individual's entrepreneurial intention (Krueger et al., 2000). Phan (2018) indicated that Mair and Noboa (2006) developed the first social entrepreneurship model based on the theory of Planned Behavior (Ajzen, 1991) and the Entrepreneurial Events model (Shapero \& Sokol, 1982).

\subsection{Empirical Studies on Determinants Influencing on Entrepreneurial Intention}

Empirical studies until now have shown that there are four main groups of determinants that have influence on the intention to start a business, including, Psychology and personality determinants, Individual background determinants, Attitudinal determinants, and Enviromental determinants.

In Vietnam, in recent years, there have been few studies on undergraduates' entrepreneurship. Until now, the topic has been exploited in two main aspects - entrepreneurial potential and entrepreneurial intention. Vietnamese scholars have begun to pay more attention to the topic of undergraduates' entrepreneurship, mainly focusing on analyzing the determinants in general influencing entrepreneurial intention of undergraduates from economics and business administration majors.

\subsection{Analytical Framework and Measurement}

Based on research goals and resources, this study used the Entrepreneurial Event Model (EEM) proposed by Shapero and Sokol in 1982 for the following reasons: Firstly, up to now, together with the Theory of Planned Behaviour (TPB) by Ajzen in 1991, the EEM model is still considered to be a reliable entrepreneurial intention model, and widely used in the world. Also, this model is regarded as the theoretical foundation for many studies (Thompson, 2009). Secondly, Krueger et al. (2000) in his study comparing TPB and EEM for their capacity to predict intention to start a business, concluded that, although both models were regarded as valuable tools in understanding how an individual forms entrepreneurial intention and decision, the Shapero model seems to explain the entrepreneurial intention better than the TPB model. On the other hand, this is also the model used specifically in the field of entrepreneurship and business, compared to diverse application of TPB proposed by Ajzen.

Based on the selected theory, this study provides an analytical framework along with three hypotheses about the determinants that influence entrepreneurial intention of National Economics University undergraduates as follows (see Figure 1):

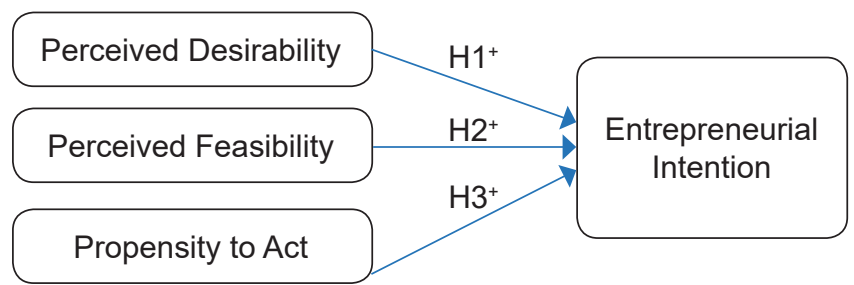

Figure 1: Research analytical framework

Source: Proposal based on EEM of Shapero and Sokol (1982)

Shapero and Sokol (1982) defined Perceived Desirability (PD) as personal attractiveness to start a business, including both inner fulfillment of and extrapersonal impacts such as finance, respect, social position. It is influenced by the attitudes, values, and perceptions of each individual. Perceived Feasibility (PF) is defined as the degree to which an indivdual feels confident when starting a business. And Shapero conceptualized Propensity to Act (PA) is as the individuals' tendency to control the situation with their own decisions and actions.

\section{Entrepreneurial Intention:}

The variable "Entrepreneurial intention" is the one related to human cognitive activities. In fact, measuring such variable is not an easy task. Therefore, the scale design in previous studies is very different. Krueger (1993) used Yes / No questions such as "Do you think you will start a business?" or used the scale of an observable variable to measure "entrepreneurial intention" with the question "Please estimate the likelihood that you will start a business in the next five years?" (Krueger et al., 2000). Kolvereid (1997) also measures "intention" by using an observation variable: "What would you prefer between starting a business and working as an employee?". In order to solve the inconsistency in measuring this variable, in 2009, Línãn and Chen developed a measurement tool of "entrepreneurial intention" and the influenced determinants by the Entrepreneurship Intentions Questionaire (EIQ). The tool of measuring "entrepreneurial intention", which was determined by Línãn and Chen (2009), has also been used in a number of studies such as analysis by Lu \& Wang (2018). In particular, the questionnaire used the Likert scale to measure "entrepreneurial intention" through affirmative statements 
showing various aspects of "entrepreneurial intention". Therefore, to measure the variable "entrepreneurial intention", this analysis inherited the scale, mainly from the study by Línãn and Chen (2009) with five observed variables and one observed variable from the scale of Leong (2008).

\section{Perceived Desirability:}

Shapero and Sokol (1982) defined "Perceived Desirability" as the attractiveness of starting a business with each subject, or the level of interest of an individual, the attitude of an individual towards startups. This paper uses a scale from previous studies with an approach similar to Shapero and Sokol's "Perceived Desirability". These are studies by Kickul and Krueger (2004), and Línãn and Chen (2009), that include four observed variables.

\section{Perceived Feasibility:}

The feasibility reflects the level of self-efficacy of each individual, the ability of each individual to perform a specific task or a certain task sequence (Krueger \& Brazeal, 1994). In the field of startup, perceived feasibility is defined as the degree to which an individual feels confident in starting a business (Shapero \& Sokol, 1982). The variable "perceived feasibility" is measured by the ability and skills that a startup needs. The scale in this study is borrowed from the "Entrepreneurial Capabilities" scale of Forbes (2005) that includes 11 observed variables.

\section{Propensity to Act:}

Shapero conceptualizes "propensity to act" as a personal tendency to act based on one's own decisions, which reflects the willful aspect of intention. According to Krueger (2000), it is also very difficult to shape an "intention" without this propensity to act. In theory, it reflects the individual's desire to control by acting. In fact, in order to measure this variable, the scale needs to be closely related to the action and persevere in pursuing an action to achieve the goal, regardless of adversity or uncertainty from the external conditions of each individual. Shapero proposes to measure this variable through a related variable, which is considered as the most relevant to the "propensity to act", that is the internal locus of control. This term was first mentioned by Rotter (1966), which reflects the extent to which each individual feels responsible for his or her own success or failure instead of depending on the underlying determinants such as luck (Fagbohungbe \& Jayeoba, 2012). To measure this variable, the author refers to a scale of "Locus of control Scale" built by Levenson in 1974 and adjusts to fit the field of start-up and inherits the scale of "Desire for control" of Burger (1985).

\section{Research Methodology}

The sample comprised full-time third-year National Economics University undergraduates from the Faculty of Management Science (with selected major Economy
Management) and the Faculty of Business Administration. The main reasons why we made that choice is that current credit-based courses at the university allow undergraduates to finish their programs within three-and-a-half years, therefore, the undergraduates selected were likely to face a career decision. In addition, for the Faculty of Management Science, Public Administration Management major undergraduates were also not included due to their main course's objectives steered toward employment in State sector.

For the sample size, we conducted a direct questionaire survey for 250 full-time third-year undergraduates at the National Economics University with convenience sampling technique. Of those 250 undergraduates, 150 were Business Administration students and 100 Economy Management students.

According to Hair et al. (2006), the sample size should be five times the number of variables in the research scales. Therefore, we consider a sample size of 250 is suitable for this study. Some 231 direct responses were collected (accounted for $92.4 \%$ of all questionaires distributed). After eliminating responses due to lack of infomation or low quality information, 215 valid responses were used $(93.07 \%$ of respondents) for data analysis.

\section{Results and Discussion}

\subsection{Descriptive Statistics}

\subsubsection{Perceived Desirability}

The results illustrate that the undergraduates who are surveyed show a high degree of desire to start a business. Most of the undergraduates agree that if they had opportunities and resources, they would definitely start-up a business (mean $=4.13$ ). In addition, they also have a positive attitude towards the startup, for instance, the "It is attractive for me to become an entrepreneur" factor $($ mean $=3.83$ ) and the "It is interesting for me to become an entrepreneur" factor $($ mean $=3.66)($ see Table 1$)$.

\subsubsection{Perceived Feasibility}

In terms of perceived feasibility or evaluating the undergraduates' self-confidence in required skills to start a business, in general, the undergraduates' level of confidence in different skills is relatively homogeneous. However, undergraduates show the lowest confidence in skills such as PF1 - "Finding good opportunities to start a business" (mean $=3.36$ ) and PF2 - "Identifying potential sources to start a business" (mean $=3.31)$ and the highest confidence in PF5 skill -" Establishing relationships for business development" (see Table 2). 
Table 1: Mean of observed variables belonging to "Perceived Desirability" factor

\begin{tabular}{|c|l|c|}
\hline Constructs & \multicolumn{1}{|c|}{ Items } & Mean \\
\hline PD1 & It is attractive for me to become an entrepreneur & 3.83 \\
\hline PD2 & It is interesting for me to become an entrepreneur & 3.66 \\
\hline PD3 & If I had the opportunities and resources, I would love to start a business & 4.13 \\
\hline PD4 & Among various options, I would rather be an entrepreneur & 3.88 \\
\hline
\end{tabular}

Table 2: Mean of observed variables belonging to "Perceived Feasibility" factor

\begin{tabular}{|c|l|c|}
\hline Constructs & \multicolumn{1}{|c|}{ Items } & Mean \\
\hline PF1 & I believe I can identify new business opportunities & 3.36 \\
\hline PF2 & I believe I can identify potential new venture funding. & 3.31 \\
\hline PF3 & I believe I can creat products or services that fulfil customers' unmet needs. & 3.61 \\
\hline PF4 & I believe I can think creatively in business. & 3.62 \\
\hline PF5 & I believe I can develop business relationships with key people & 3.80 \\
\hline PF6 & I believe I can build a team to start and run my business. & 3.43 \\
\hline PF7 & I believe I can inspire those I work with to share my business vision & 3.65 \\
\hline PF8 & I believe I can work productively under continuous pressure from work & 3.60 \\
\hline PF9 & I believe I can tolerate unexpected changes in business conditions & 3.53 \\
\hline PF10 & I believe I can persist in the face of business setbacks & 3.58 \\
\hline PF11 & If I wanted to, I believe I could successfully start my own business. & 3.64 \\
\hline
\end{tabular}

Table 3: Mean of observed variables belonging to "Propensity to Act" factor

\begin{tabular}{|c|l|c|}
\hline Constructs & \multicolumn{1}{|c|}{ Items } & Mean \\
\hline PA1 & Whether or not I can start a business depends mostly on my abilities. & 3.74 \\
\hline PA2 & When I start my own business successfully, it's usually because I worked hard for it & 3.89 \\
\hline PA3 & My life is determined by my own actions. & 4.21 \\
\hline PA4 & I would rather make my own mistake than to take orders from someone else. & 3.85 \\
\hline PA5 & $\begin{array}{l}\text { When I am faced with a problem, I prefer to do something about it rather than sit by } \\
\text { and let it continue. }\end{array}$ & 4.10 \\
\hline PA6 & I enjoy making my own decisions. & 3.73 \\
\hline PA7 & I always try to demonstrate a leadership when I am in group projects. & 3.62 \\
\hline
\end{tabular}

\subsubsection{Propensity to Act}

The "propensity to act" factor indicates the perceived control of an individual by acting. Based on the results of the survey, the undergraduates' propensity to act is assessed at a relatively high level. In particular, the undergraduates agree that "My life is determined by my own actions" - PA3 (mean $=4.21$ ) and "When a problem arises, I want to do something more than just sitting and letting it continue" - PA5 (mean $=4.10$ ). Meanwhile, not many undergraduates choose "I always try to demonstrate a leadership when I am in group projects" - PA7 (see Table 3).

\subsection{Cronbach's Alpha}

Cronbach's Alpha statistics illustrate that the "Entrepreneurial Intention", "Perceived Desirability", and the "Prospensity to Act" scale have the reliability score of 0.858 , 0.812 , and 0.751 , respectively. The "Perceived Feasibility" scale has a Cronbach's Alpha of 0.853 after the removal of the item PF5 due to a Corrected Item-Total Correlation of less than 0.3, and scale with the Cronbach's Alpha is. Thus, based on the criteria provided by Hair et al. (2006), all scales assure reliability, and all items were accepted and used for Explanatory Factor Analysis (except for item PF5). 


\subsection{Explanatory Factor Analysis (EFA)}

The initial research model consists of three independent variables with 22 items that are expected to influence the entrepreneurial intention of National Economics University undergraduates. However, after the Cronbach's Alpha coefficient test was verified, the item PF5 was excluded from the "Perceived Feasibility" scale. Hence, the remaining 21 items would be included in the EFA analysis. After conducting EFA, seven items were excluded due to their loading factors of less than 0.55 . The remaining 15 items are grouped into four determinants (see Table 4). For scale description, see Appendix.

However, some items did not converge as the research model proposed. Some items inherently belong to the scale "Perceived Feasibility" and were separated into two distinct factors. In detail, three items PF1, PF2, PF3 were converged into one factor; four other items PF7, PF8, PF9, PF10 were converged into one factor.

This proves that the scale "Perceived Feasibility" is a multi-dimensional scale. This result is supported by Jeffery et al. (2009). As per EFA results, there are four determinants influencing undergraduates' entrepreneurial intention with rearrangements of some items compared to the initial research model (composed of three determinants). Those determinants are renamed as follows:

Factor 1 (F1) includes four items PD1, PD2, PD3, PD4, which were named as the initial research model "Perceived Desirability";

Table 4: Rotated Component Matrix

\begin{tabular}{|c|c|c|c|c|}
\hline & \multicolumn{4}{|c|}{ Component } \\
\hline & $\mathbf{1}$ & $\mathbf{2}$ & $\mathbf{3}$ & $\mathbf{4}$ \\
\hline PD1 & 0.806 & & & \\
\hline PD2 & 0.856 & & & \\
\hline PD3 & 0.772 & & & \\
\hline PD4 & 0.696 & & & \\
\hline PF1 & & & 0.850 & \\
\hline PF2 & & & 0.754 & \\
\hline PF3 & & & 0.712 & \\
\hline PF7 & & 0.655 & & \\
\hline PF8 & & 0.661 & & \\
\hline PF9 & & 0.780 & & \\
\hline PF10 & & 0.741 & & \\
\hline PA1 & & & & 0.747 \\
\hline PA2 & & & & 0.764 \\
\hline PA3 & & & & 0.703 \\
\hline
\end{tabular}

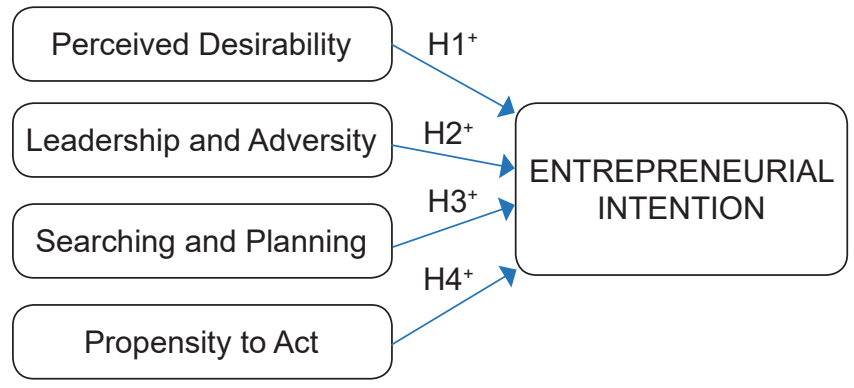

Figure 2: Adjusted research model

Factor 2 (F2) consists of four items PF7, Pf8, PF9, PF10. These items were separated from "Perceived Feasibility" scale, representing the capabilities of leadership as well as facing with changes, stress, and difficulties of each individual. This factor was named as "Leadership and Adversity";

Factor 3 (F3) consists of three items PF1, PF2, PF3, which were separated from "Perceived Feasibility" scale. Based on entrepreneurial self-efficacy model provided by Jeffery et al. (2009), we named this factor as "Searching and Planning";

Factor 4 (F4), consisting of three items PA1, PA2, PA3, was named as in the initial research model "Propensity to Act".

As new determinants were formed, the reliability for each new scale was examined once again. The results show that the Cronbach's Alpha coefficient for new scales all meet the criteria for reliability.

Thus, following EFA analysis, the model was adjusted as follows (see Figure 2):

\subsection{Linear Regression Analysis}

To identify determinants affecting the undergraduates' entrepreneurial intention, the correlation model can be formed as $E I=f(F 1, F 2, F 3, F 4)$. Of which, EI: dependent variable; F1, F2, F3, F4: independent variables. Examining factors F1 through F4, which factors really affect the undergraduates' entrepreneurial intention directly, will be done by the linear regression equation:

$$
E I=\beta 0+\beta 0 F 1+\beta 0 F 2+\beta 3 F 3+\beta 4 F 4+\text { ei }
$$

Of which, the variables included in the regressioni analysis are determined by calculating the factor scores.

Factor F1 through F4 are quantified:

\section{$\mathrm{Fi}=\mathrm{Wi1X1}+\mathrm{Wi2X} 2+\ldots . .+$ WikXk}

With Wik: Componet Score Coefficient; Xi: items of factor i.

In Table 5, Adjusted $\mathrm{R}^{2}$ is 0.545 . This shows that $54.5 \%$ change in entrepreneurial intention of undergraduates is explained by four independent variables given in the model. 
Thi Hong Viet BUI, Thi Le Thuy NGUYEN, Manh Dung TRAN, Thi Anh Thu NGUYEN /

Journal of Asian Finance, Economics and Business Vol 7 No 7 (2020) 369 - 378

Table 5: Model Summary

\begin{tabular}{|c|c|c|c|c|c|c|c|c|c|}
\hline \multirow{2}{*}{ Model } & \multirow{2}{*}{$\mathbf{R}$} & \multirow{2}{*}{$\mathbf{R}^{2}$} & \multirow{2}{*}{ Adjusted $\mathbf{R}^{2}$} & \multirow{2}{*}{$\begin{array}{c}\text { Std.Error of } \\
\text { the Estimate }\end{array}$} & & \multicolumn{5}{|c|}{ Change Statistics } \\
\cline { 5 - 10 } & & & & $\mathbf{R}^{2}$ change & F change & df1 & df2 & Sig. F change \\
\hline 1 & $.744^{a}$ & .554 & .545 & .67421824 & .554 & 65.194 & 4 & 210 & .000 \\
\hline
\end{tabular}

Table 6: ANOVA analysis

\begin{tabular}{|c|c|c|c|c|c|}
\hline Model & Sum of Squares & df & Mean square & F & Sig. \\
\hline Regression & 118.540 & 4 & 29.517 & 65.194 & $.000^{\mathrm{b}}$ \\
Residual & 95.460 & 210 & .455 & & \\
Total & 214.000 & 214 & & & \\
\hline
\end{tabular}

Table 7: Coefficients

\begin{tabular}{|l|c|c|c|c|c|}
\hline \multirow{2}{*}{ Model } & \multicolumn{2}{|c|}{$\begin{array}{c}\text { Unstandardized } \\
\text { Coefficients }\end{array}$} & $\begin{array}{c}\text { Standardized } \\
\text { Coefficients }\end{array}$ & \multirow{2}{*}{ Sig } \\
\cline { 2 - 5 } & B & Std. Error & Beta & & \\
\hline \multicolumn{1}{|c|}{ Constant } & .000 & .046 & & 1.000 \\
\hline F1 -Perceived Desirability & .652 & .046 & .652 & 14.154 & .000 \\
\hline F2 -Leadership and Adversity & .177 & .046 & .177 & 3.847 & .000 \\
\hline F3 -Searching and Planning & .287 & .046 & .287 & 6.217 & .000 \\
\hline F4 -Prospensity to Act & .122 & .046 & .122 & 2.645 & .009 \\
\hline
\end{tabular}

In Table 6, with Sig. $<0.01$, it can be concluded that given model is consistent with the data, or, in the other words, the independent variables have linear correlation with the dependent variable, with a reliability level of $99 \%$.

In Table 7, the Sig. column shows that all variables F1, F2, F3, F4 have Sig. $=0.000$ less than 0.01 . Therefore, F1, F2, F3, F4 have significant correlation with Ei with reliablity of $99 \%$. Following the results, it is possible to rewrite the linear regression equation with the dependent variable as Entrepreneurial Intention as follows:

$$
\mathrm{EI}=0,652 \mathrm{~F} 1+0,177 \mathrm{~F} 2+0,287 \mathrm{~F} 3+0,122 \mathrm{~F} 4
$$

The equation shows that all unstandardized coefficients of variables F1, F2, F3 are greater than 0 with $p<0.01$. This demonstrates that four independent variables have a positive relationship with entrepreneurial intention.

\section{Conclusion and Recommendation}

The regression analysis results illustrate that:

Firstly, the results confirm the effect of perceived desirability, and this is also the strongest relationship with entrepreneurial intention. This shows that the desire as well as the motivation to start a business or become an entrepreneur have the biggest impact on students' career choices. Besides, it is also possible to understand that National Economics
University undergraduates have positive perceptions and tendencies for entrepreneurship. This hypothesis is also supported by some other studies elsewhere in the world such as in Turkey with Uysal (2016) and in Sri Lanka with Dissanayake (2013).

Secondly, results also show the positive impact of perceived feasibility on entrepreneurial intention. Of which, undergraduates' ability to search and plan to start a business has a stronger influence on their entrepreneurial intention than their ability to lead or overcome adversity. This may imply that simply increasing the undergraduates' perceived feasibility in identify start-up opportunities, potential sources of funds, creativity, and the ideas of products or services they want to provide, may strengthen their entrepreneurial intention. This result will be useful for the orientation of the university's policies for student-related activities, including both curricular and extra-curricular activities, which should be targeted to drive undergraduates towards undergraduates' self-confidence in finding opportunities as well as planning their start-ups.

Thirdly, the hypothesis on the positive relationship between undergraduates' propensity to act and their intention to start a business is also supported in this study. This means that when they are more inclined to act or decide on their own, their intention to start a business is stronger. However, the results also show that the influence of propensity to act factor on entrepreneurial intention is very modest. The results confirm the analysis of some previous studies using 
Shapero and Sokol models such as Ngugi et al. (2012), and Thuo et al. (2016).

The results show that increased awareness/perception of the desire, the ability to search and plan for starting a business, ability to lead and overcome adversity, and also propensity to act can increase undergraduates' entrepreneurial intention. Therefore, in order to nurture the entrepreneurial intention or spirit, the university needs to have specific ways to influence all four determinants, from which, undergraduates can be more interested in entrepreneurship and more confident in entrepreneurial related activities.

This can be achieved through two main ways: entrepreneurship education and entrepreneurship favorable environment. In order to increase entrepreneurial intention, the university should promote the entrepreneurship education in the following directions:

First, increase practicality and application in the lecture. Teaching should minimize theoretical knowledge to increase undergraduates' practice and application time. This is considered to be one of the most important aspects of entrepreneurship education, because if undergraduates have only theoretical access, they can feel passive and cannot transform that knowledge into their own knowledge and also necessary practical skills. In order to do this, lecturers need to encourage the undergraduates' creative and innovative thinking through lessons. They can combine problem-based and project-based methodology for undergraduates to be able to put their ideas, plan for their start-up business, and improve their creative and problem-solving capabilities. In addition, case studies are also an effective way to increase undergraduates' curiosity, putting them in real-life entrepreneurial situations. By learning from success and failure start-up stories, undergraduates can dig deeper into thinking process that entrepreneurs have gone through to make decisions such as case analysis, assessing possibilities, choosing solutions and follow up their plan. In addition, during teaching process, the lecturers should pay due attention to train undergraduates' skill such as identifying potential funds or opportunities for starting a business. Those are skills, which the undergraduates feel least confident in, according to the research results.

Second, the university may invite entrepreneurs, alumni of National Economics University who started their business and gone through the start-up phase successfully to give lectures on some entrepreneurship topics, and share their experience with undergraduates. The combination of sharing, or discussing, and learning with entrepreneurs can make starting a business more attractive approachable to undergraduates. Undergraduates can visualize in a more realistic way how to start a business, the knowledge, skills they need, and how each entrepreneur went through difficult times, or failure. In particular, if entrepreneurs can inspire undergraduates, this can be a very effective way for undergraduates to feel enticed to start a business and thereby, motivating their entrepreneurial intention.

Third, including entrepreneurship course in training programs in other major beside Business Administration. Results prove that the group of undergraduates who studied the subject of entrepreneurship is more likely to start a business than the group who did not. On the other hand, improving start-up skills can be supported by educational activities. Thus, addition of entrepreneurship subject to training programs of other majors can help other undergraduates gain additional tools and confidence when starting a business. Moreover, this also promotes and help spread entrepreneurial spirit throughout the National Economics University, which can also positively impact undergraduates in general at other universities in Hanoi as well.

In addition, the university should establish entrepreneurship education outside the lectures by building an environment to encourage entrepreneurship as below:

(i) Encouraging undergraduates to set up a start-up club, actively participate in start-up contests, not only at university level, but city and country level as well. This can help undergraduates and young people sharing the same passion for learning about business, exchange experience with each other and have real experience. It is the formation of a community that can be supportive as in the club or competitive as in contests, can have positive impact on the undergraduates' desire to start a business.

(ii) Building a cooperation "University - Enterprises" model and establish a business incubator based on this cooperation. The goal of the center is to allow undergraduates and faculty to work on projects mandated by participating enterprises, especially small and medium ones. Projects may involve providing enterprises with market research they are targeting, as well as new ideas for competitive strategies.

\section{References}

Ajzen, I. (1987). Attitudes, traits, and actions: Dispositional prediction of behaviour in personality and social psychology. Advances in Experimental Social Psychology, 20, 1-63.

Ajzen, I., \& Fishbien, M. (1980). Understanding Attitudes and Predicting Social Behaviour. Englewood Cliffs, New Jersey: Prentice-Hall.

Ajzen, I. (1991). The theory of planned behaviour. Organizational Behaviour and Human Decision Processes, 50, 179-211.

Amari, F., Abbes, I., \& Boudabbous, S. (2014). The Influence of individual factors on the entrepreneurial intention. International Journal of Managing Value and Supply Chains, 5(4), 47-57.

Bird, B. (1998). Implementing Entrepreneurial Ideas: The Case for Intention. Academy of Management Review, 13, 442-453.

Burger, J. M. (1985). Desire for Control and Achievement-related behaviours. Journal of Personality and Social Psychology, 48(6), 1520-1533. 
Bygrave, W. D., \& Timmons, J. A. (1992). Venture capital at the crossroads. Boston, MA: Harvard Business School Press.

Dissanayake, D.M.N.S.W., (2013). The Impact of Perceived Desirability and Perceived Feasibility on Entrepreneurial Intention among Undergraduate Students in Sri Lanka: An Extended Model. The Kelaniya Journal of Management, 2(1), 39-57.

Drucker, P. F (1985). Innovation and Entrepreneurship: Practice and Principles. New York, NY: Harper Business.

Fagbohungbe, O. B., \& Jayeoba, F. I. (2012). Locus of Control, Gender and Entrepreneurial Ability. British Journal of Arts \& Social Sciences, 11(1), 74-85.

Forbes, D. (2005). The effects of strategic decision making on entrepreneurial self-efficacy. Entrepreneurial Theory and Practice, 29(5), 599-626.

Gartner, W. B. (1985). A conceptual framework for describing the phenomenon of new venture creation. Academy of Management Review, 10(4), 696-706.

Guerrero, M., Rialp, J., \& Urbano, D. (2008). The impact of desirablitily and feasibility on entrepreneurial intentions: a structural equation model. International Entrepreneurship and Management Journal, 4, 35-50.

Hair, J. F., Black, W. C., Babin, B. J. \& Anderson R. E. (2006). Multivariate Data Analysis. (6 ${ }^{\text {th }}$ Ed.), London, UK: Pearson Education.

Hisrich, R., Peters, M., \& Shepherd, D. (2005). Entrepreneurship. (6 ${ }^{\text {th }}$ Ed.). New York, NY: McGraw-Hill.

Jefferey, E. M., Mark, P., Stephen, L. M., \& Jenifer, M. S (2009), Entrepreneurial Self-Efficacy: Refining the Measure. Entrepreneurship Theory and Practice, 33(4), 965-988.

Kickul, J., \& Krueger, N. (2004), A cognitive processing model of entrepreneurial self-efficacy and intentionality. Frontiers of Entrepreurship Research, Wellesley, MA: Babson College.

Kolvereid, L. (1997). Prediction of employment status choice intentions. Entrepreneurship Theory and Practice, 21, 47-57.

Krueger, N. F. (1993). The impact of prior entrepreneurial exposure on perceptions of new venture feasibility and desirability. Entrepreneurship Theory and Practice, 18(1), 5-23.

Krueger, N. F., \& Brazeal, D. V. (1994). Entrepreneurial Potential and Potential Entrepreneurs. Entrepreneurship Theory and Practice, 18(3), 91-104.

Krueger, N. F., Reily, M. D., Carsrud, A. (2000). Competing models of entrepreneurial intention. Journal of Business Venture, 15, 411-432.

Leong, C. K. (2008). Entrepreneurial Intention: An Empirical Study Among Open University Malaysia Students. Malaysia: Doctoral dissertation, Open University Malysia Center for Graduate Studies.

Levenson, H. (1974). Activisism and powerful others: distinctions within the concept of internal-external control. Journal of Personality Asessment, 38, 377-383.
Línãn, F., \& Chen, Y. W. (2009). Development and cross-cultural application of a specific instrument to measure entrepreneurial intentions. Entrepreneurship Theory and Practice, 33(3), 593617.

Lu, H., \& Wang, J. (2018). Entrepreneurial Intention of Two Patterns of Planned Behaviour and Alertness: Empirical Evidence in China. Journal of Asian Finance, Economics and Business, 5(2), 63-72. https://doi.org/10.13106/jafeb.2018.vol5.no2.63

Mair, J., \& Noboa, E. (2006). Social entrepreneurship: How intentions to create a social venture are formed Social Entrepreneurship (pp.121-135). New York: Springer.

Morris, M. H, Lewis, P. S., \& Sexton, D. L. (1994). Reconceptualizeing Entrepreneurship: An input - output Perspective. Advanced Management Journal, Winter, 29-30.

Ngugi, J. K., Gakure, R.W., \& Waithaka, S.M. (2012). Application of Shapero's Model in Explaining Entrepreneurial Intentions among University Students in Kenya. International Journal of Business and Social Research, 2(4), 125-148.

Parker, S. C. (2004). The Economics of self-employment and Entrepreneurship. Cambridge University Press, UK.

Parker, S. C. (2009). The Economics of Entrepreneurship. New York, NY: Cambridge University Press,

Phan, T. L. (2018). The Relationship between Perceived Access to Finance and Social Entrepreneurship Intentions among University Students in Vietnam. Journal of Asian Finance, Economics and Business, 5(1), 63-72. http://dx.doi. org/10.13106/jafeb.2018.vol5.no1.63

Robinson, P. B., Stimpson, D., Huefner, J. C., \& Hunt, H. K. (1991). An attitude approach to the prediction of entrepreneurship. Entrepreneurship Theory and Practice, 15(4), 13-31.

Rotter, J. B. (1966). Generalized expectancies for internal versus external control of reinforcement. Psychological Monographs, 80(1), 1-28.

Schumpeter, J. (1934). The theory of Economic Development: An Inquiry into Profits, Capital, Credit, Interest, and the Business Cycle. Cambridge, MA: Harvard University Press.

Shane, S., \& Venkataraman, S. (2000). The Promise of Entrepreneurship as a Field of Research. The Acadmy of Management Review, 25(1), 217-226.

Shapero, A., \& Sokol, L. (1982). Social Dimensions of Entrepreneurship. Encyclopedia of Entrepreneurship, 72 - 90. Englewood Cliffs, New Jersey: Prentice-Hall.

Thompson, E. (2009). Individual entrepreneurial intent: Construct clarification and development of an internationally reliable metric. Entrepreneurship Theory and Practice, 33(3), 669-694.

Thuo, M., Abo, T., \& Toma, S. (2016). Entrepreneurial Intentions of University Students: Insights for Entrepreneurial Education in Ethiopia. European Journal of Business and Management, $8(22), 25-35$.

Uysal, B. (2016). Entrepreneurial Intentions of University Students: A Comparison between Kosovo and Turkey Using Shapero's Model. Review of Economic and Business Studies, 9(2), 29-44. 
Appendix 1: Scale description

\begin{tabular}{|c|c|c|c|}
\hline \multicolumn{2}{|c|}{ Construct } & Items & Sources \\
\hline \multirow{5}{*}{$\begin{array}{l}\text { Entrepreneurial } \\
\text { Intention }\end{array}$} & El1 & $\begin{array}{l}\text { I prefer to be an entrepreneur rather than to be an employee in a } \\
\text { company/organization }\end{array}$ & Leong (2008) \\
\hline & $\mathrm{El} 2$ & I have a very serious thought about starting my own firm. & \multirow{4}{*}{$\begin{array}{l}\text { Línãn \& Chen } \\
\qquad(2009)\end{array}$} \\
\hline & El3 & My professional goal is to become an entrepreneur. & \\
\hline & El4 & I'm determined to create a firm in future & \\
\hline & El5 & I am ready to do anything to be an entrepreneur. & \\
\hline \multirow{4}{*}{$\begin{array}{l}\text { Perceived } \\
\text { Desirability }\end{array}$} & PD1 & It is attractive for me to become an entrepreneur. & \multirow{2}{*}{$\begin{array}{c}\text { Kickul \& Krueger } \\
(2004)\end{array}$} \\
\hline & PD2 & It is interesting for me to become an entrepreneur & \\
\hline & PD3 & If I had the opportunities and resources, I would love to start a business. & \multirow{2}{*}{$\begin{array}{l}\text { Línãn \& Chen } \\
\qquad(2009)\end{array}$} \\
\hline & PD4 & Among various options, I would rather be an entrepreneur. & \\
\hline \multirow{11}{*}{$\begin{array}{l}\text { Perceived } \\
\text { Feasibility }\end{array}$} & PF1 & I believe I can identify new business opportunities & \multirow{11}{*}{ Forbes (2005) } \\
\hline & PF2 & I believe I can identify potential new venture funding. & \\
\hline & PF3 & $\begin{array}{l}\text { I believe I can creat products or services that fulfil customers' unmet } \\
\text { needs. }\end{array}$ & \\
\hline & PF4 & I believe I can think creatively in business. & \\
\hline & PF5 & I believe I can develop business relationships with key people & \\
\hline & PF6 & I believe I can build a team to start and run my business. & \\
\hline & PF7 & I believe I can inspire those I work with to share my business vision & \\
\hline & PF8 & I believe I can work productively under continuous pressure from work & \\
\hline & PF9 & I believe I can tolerate unexpected changes in business conditions & \\
\hline & PF10 & I believe I can persist in the face of business setbacks & \\
\hline & PF11 & If I wanted to, I believe I could successfully start my own business. & \\
\hline \multirow{7}{*}{$\begin{array}{l}\text { Propensity } \\
\text { to Act }\end{array}$} & PA1 & Whether or not I can start a business depends mostly on my abilities. & \multirow{3}{*}{ Levenson (1974) } \\
\hline & PA2 & $\begin{array}{l}\text { When I start my own business successfully, it's usually because I worked } \\
\text { hard for it }\end{array}$ & \\
\hline & PA3 & My life is determined by my own actions. & \\
\hline & PA4 & $\begin{array}{l}\text { I would rather make my own mistake than to take orders from someone } \\
\text { else. }\end{array}$ & \multirow{4}{*}{ Burger (1985) } \\
\hline & PA5 & $\begin{array}{l}\text { When I am faced with a problem, I prefer to do something about it rather } \\
\text { than sit by and let it continue. }\end{array}$ & \\
\hline & PA6 & I enjoy making my own decisions. & \\
\hline & PA7 & I always try to demonstrate a leadership when I am in group projects. & \\
\hline
\end{tabular}

